\title{
LADINA KEELEST PÄRIT TERMINITE POLÜSEEMIA JA SÜNONÜÜMIA EESTI ÕIGUSKEELES
}

\section{Merike Ristikivi}

Ülevaade. Artikkel käsitleb ladina keelest pärit õigusterminite polüseemia ja sünonüümia probleeme. Alusmaterjalina on kasutatud "Ladina-eesti õigussõnastiku" (2005) ainest. Ehkki Euroopa õigusmõtlemine baseerub ühisel Rooma õiguse pärandil ning sellest võrsunud terminid on õigussüsteemides juurdunud, esinevad ladina terminid juriidilistes materjalides sageli erinevas tähenduses, kusjuures erinevused on ka õigussüsteemide ja õigusperekondade terminite vahel. Samuti võib leida sama mõiste tähistajana mitu erinevat terminit. Artikkel analüüsib, millistel juhtudel on polüseemia ja sünonüümia ladina õigusterminoloogias taunitavad, missugustel aga mõistlikud ja otstarbekad.

Võtmesõnad: õiguskeel, terminoloogia, terminisõnastikud, leksikaalne semantika, keelekontaktid, polüseemia, sünonüümia, ladina keel, eesti keel

\section{Sissejuhatus}

Õigusteadus ja juriidiline praktika on valdkonnad, kus keelelistel väljendusvahenditel on eriliselt suur tähtsus. Nad mõlemad toimivad vahetult keele kaudu, sõna või väljend omandab seal juriidilise jõu. Seepärast on õiguskeele küsimused päevakorral ja nende olulisust tajuvad nii keelega kui juriidikaga tegelejad. Parimad praktilised väljundid sünnivad kahe valdkonna koostöös.

Selles küsimusteringis on üheks keskmeks ladina keelest pärit sõnad ja väljendid, mida õiguskeeles kasutatakse tsitaatsõnadena või eesti keeles mugandunud kujul. Ent kuidas toimib õiguskeele raames kahe keele vastastikune suhe? Siin tuleb vaatluse alla keeleküsimuste leksikaalne ja semantiline külg. ${ }^{1}$ Analüüsitav materjal pärineb 2005. aastal ilmunud "Ladina-eesti õigussõnastiku" (Adomeit jt 2005) ainest. Selle sõnastiku koostamisel kasutatud erinevate juriidiliste materjalide uurimisel ilmnes, et ladina termineid kasutatakse sageli eri tähendustes, kusjuures 
erinevused on ka õigussüsteemide ja õigusperekondade terminite vahel. Samuti võib leida sama mõiste tähistajana mitu eri terminit. Eesti õiguskeele kujundamisel ja korrastamisel on vajalik selle nähtuse tausta tundmine ja eesti keele seisukohalt vajaliku analüüsi ning järelduste tegemine, mis tagaks ladina keelevahendite asjakohase kasutamise. Seda senini tehtud pole ja käesolevas artiklis toodud analüüs selgitab mõningaid külgi selleks küsimuses.

Ladina keele ja sealt pärit väljendite osa õiguskeeles vajab süvendatud tähelepanu, kuna siin ilmnevad probleemid väljendusviisi täpsuses ja korrektsuses. Samas on ladina keele osa õiguskeeles säilitanud oma tähtsuse läbi sajandite - nii. teatud õigusteaduse aladel kui praktilises väljendusviisis. Nende küsimustega tegelemine annab tulemusi interdistsiplinaarse lähenemise raames, kus eri valdkonnad püüavad pakkuda lahendusi, arvestades üksteise eripära. Käesolev artikkel püüab esitada probleeme ja leida neile vastuseid, vaadeldes latinisti pilguga õiguskeeles esinevaid keeleküsimusi.

Leksika seisukohalt vaatlen ladina keelest pärit õigusterminite leksikaalseid, grammatilisi, ortograafilisi ning lühivariante.

Semantika osas tõusevad esile järgmised probleemid: ladina terminite tähendus üld- ja õiguskeeles, tähenduserinevused õigussüsteemide ja -perekondade terminoloogias ning mitmetähenduslikud terminid, mis tähistavad üksteisele lähedal seisvaid mõisteid.

\section{Ladina õigusterminite polüseemia}

Oskuskeele üldine püüe võimalikult täpse ja ühemõttelise väljenduse poole tingib, et ühele terminile vastaks ainult üks mõiste ning vastupidi, ühele mõistele vastaks ainult üks termin. Seega on ideaalnõue, et oskuskeel oleks vaba nii polüseemiast kui ka sünonüümiast (Erelt 1982: 37; Kull 2000c: 552 jj). Siiski pole absoluutne ühetähenduslikkus kooskõlas keele funktsioneerimise põhialustega. Teaduses ja ka praktilisel oskusalal võib väljenduse mitmekujulisus osutuda mitte ainult häiretuks, vaid ka kasulikuks (Saari 1980a: 662). Nii tuleb terminite mõistelise täpsustamise kui ka nende mitmesugustes variantides ja nende omadustes selguse saamiseks jälgida neid tegelikus tarvituses, kontekstis (Kull 2000a: 117). Seejuures tuleb silmas pidada, et nii laiendava kui ka kitsendava tõlgendamise korral vastab termini sisu vastavas kohas ja ajas valitsevatele vaadetele või teistele õigusvälistele tingimustele (Oksaar 1999: 203-204).

Mitmetähenduslikkus võib oskuskeeles tekkida järgmistel põhjustel:

1) oskuskeel on loomulik-tehislik allkeel. See tähendab muu hulgas sedagi, et ühelt poolt on temas võimalik taotleda ja ka saavutada terminite ühetähenduslikkust ning semantilist rangust, teiselt poolt toimivad loomuliku keele seaduspärasused. Termini kasutus võib kitseneda, laieneda, nihkuda teiste mõistete peale, semantilised piirid aga seetõttu tuhmuvad ning areneb välja mitmetähenduslikkus (Erelt 1982: 37);

2) tihti tuleb ühel ja samal terminil tähistada küll ühe ja sama nähtuse juurde kuuluvaid, aga juba eri mõisteid ${ }^{2}$ : vanad mõisted jäävad kõrvale, asemele tulevad uued. Ent mõnda aega eksisteerivad vana ja uus kõrvuti, käivad küll samade asjade kohta, aga on täiesti erinevate vaadete või hüpoteeside

2 Termini mitmetähenduslikkuse tekkimist ajaloolises arengus nimetatakse ka diakrooniliseks polüseemiaks (Cornu 1990: 98). 
tulemused, täis erinevat sisu (Erelt 1982: 38), õigusteaduslikus kontekstis eriti näiteks ladina terminid ius civile ja ius commune (vt allpool 1.1.3). Selline polüseemia kajastab teaduse arenguprotsessi, sama teadusharu raames erinevate teooriate lahknevusi, põhimõtteliste seisukohtade muutusi.

Polüseemianähtused võib jagada kahte rühma selle järgi, kas mitmetähenduslik termin tähistab üksteisest kaugel seisvaid või üksteisele lähedal seisvaid mõisteid. ${ }^{3}$

\section{1. Üksteisest kaugel seisvate mõistete tähistamine}

\subsection{1. Üld- ja õiguskeelne tähendus}

Kui mitmetähenduslik termin tähistab üksteisest kaugel seisvaid mõisteid, ei ole need kas üldse seotud või on kauges suguluses. Ladina keeles võib tuua näiteks järgmised terminid: actio üldkeelne tähendus 'tegevus, toiming, tegu', õiguskeeles (edaspidi lühendatultjur) 'hagi, nõue, kaebus'; animus 'vaim, hing, meel', jur 'tahe, tahtlus, kavatsus'; caput 'pea; pealinn; peatükk',jur ‘õigusvõime'; causa 'põhjus', jur 'protsess, kohtuasi'; dolus 'kavalus, kaval inimene', jur 'tahtlus, pettus, tüssamine'; manus 'käsi, jõuk', jur ‘(perekonnapea) võim'; societas 'ühiskond; ühendus', jur 'seltsinguleping'..

Kui sama sõna kasutatakse nii erinevates süsteemides nagu üldkeel ja õiguskeel, siis suuremaid segiminekuvõimalusi praktiliselt pole. Ka erialakeeles võib üldkeele tähendus esineda tegevuse või nähtuste üldise iseloomu või omaduse kirjeldamisel. Tõlkimisel osutab kontekst, millises tähenduses sõna väljendis või lauses esineb, näiteks actio culposa 'süüline tegevus', jur actio in rem 'asjaõiguslik hagi', actiones transeunt ad heredes 'ñouded lähevad üle pärijatele'; aequo animo 'rahuliku meelega', jur animus possidendi 'valdamise tahe'; causa mortis 'surma põhjus', jur causa civilis 'tsiviilprotsess'; manu propria 'oma käega, omakäeliselt', jur matrimonium sine manu 'abielu ilma (mehe) võimuta'..

\subsection{2. Õiguskeelesisene mitmetähenduslikkus ladina keele traditsioonis}

Sellesse rühma liigitatakse terminid, millel on oskuskeele enda sees erialati erinevad tähendused. Ladina keeles on culpa ja delictum tuntumad terminid, millel on eri õigusharudes kujunenud erinevad tähendused. Näiteks tähistab termin culpa tsiviilõiguses hooletust, karistusõiguses aga on tähenduseks 'ettevaatamatus, süü'. Tsiviilõiguses on delictum 'õigusvastane kahjutekitamine', karistusõiguses tähistab see termin süütegu, kuritegu.

Ehkki Euroopa õigusmõte baseerub ühisel Rooma õiguse pärandil ning sellest võrsunud terminid on juurdunud kõigis Euroopa õigussüsteemides, on rahvusvahelise kogemusega juristid tähele pannud, et välismaa kolleegide õigusalast ladina keelt ei ole alati kerge mõista (Berteloot 1999: 2). Samad terminid ei ole kõikjal kasutusel, samuti võib olla erinevusi terminite tähenduses. Suurimad erinevused ladina väljendite tähenduste vahel on angloameerika ${ }^{4}$ ja Mandri-Euroopa õigussüsteemide terminoloogias (Cornu 1990: 104). Nendes suurtes õiguskultuurides erinevad jurii-

3 Polüseemia liigitamisel on lähtutud T. Erelti (1982: 38-40) ja G. Cornu (1990: 95-102) jaotusest.

${ }^{4}$ Läänelik õigustraditsioon jaguneb Mandri-Euroopa (kontinentaalseks, romaani-germaani) ning angloameerika (common law) õigussüsteemiks. Eri õigussüsteemides erineb ka keeleline väljendusviis, sealhulgas sõnavara. Õigussüsteeme iseloomustavad erinevad õigusfilosoofilised käsitlused riigist ja õigusest, erinevad on arusaamad õiguse reguleerivast rollist ühiskonnas, õiguse allikatest ning õigusnormist, õiguse loomisest ning realiseerimisest. Erinevustele vaatamata on läänelikku õigustraditsiooni kuuluvate õigussüsteemide teoreetiliste koolkondade põhiliseks probleemiks üksikisiku ja ühiskonna, seega erahuvi ja avaliku huvi vahekord (Anepaio jt 2005: 167-168). Mandri-Euroopa õigussüsteemi 
dilise ladina keele traditsioonid üksteisest märgatavalt. Etümoloogiline taust tingib sel puhul mingi ühisosa säilivuse semantilisel väljal. Lahknevate osade maht võib eri mõistete puhul erineda, ulatudes suhteliselt lähedasest märgatava erisuseni.

Kontekstiväliselt võib vääriti mõistmist põhjustada näiteks termin ius commune, mis tähistab Mandri-Euroopa ühisõigust ning on välja kujunenud Rooma ja kanoonilise õiguse allikate teadusliku käsitluse tulemusena. Angloameerika sõnastike vaste sellele on common law, mis märgib Inglismaa vana, kohtupraktikaga kujundatud õigust. ${ }^{5}$

Termin exitus tähistab Mandri-Euroopa juriidikas surma, common law sõnastikud aga annavad vasteks 'lapsed, järglased' või ka 'renditulud; ekspordimaks'. ${ }^{6}$ Ühisosa tähistab siin millestki eraldumist, lahknev osa eraldumise variante. Termin breve tähendus saksa õigussõnastikes on 'kiri; lühike paavsti läkitus', common law ajaloos tähistab see mõiste aga nõuet kohtusse ilmumiseks, kohtukutset.7 Mõlema termini aluseks on läkituse üks omadus - lühidus.

Põhiosa Mandri-Euroopa õigussüsteemis kasutatavatest ladina väljenditest on käibel sama tähendusega. Romaani-germaani õigusperekonna ${ }^{8}$ väljendite sarnasus on paljuski tingitud Mandri-Euroopa maade ühisest ius commune pärandist. ${ }^{9} 18$. sajandi lõpuni oli Mandri-Euroopa õigusteadus oma iseloomult rahvasteülene. Eri maade õpetlased uurisid ja edendasid õigust ladina keeles rahvuspiiridest sõltumata. Siiski võib ka siin leida väljendeid, mille tähendused ei lange osaliselt või mõnel juhul isegi täielikult kokku. ${ }^{10}$ Näiteks ladina sõna conventio tähendus germaani õigusperekonnas on 'leping, kokkulepe'; romaani õigusperekonnas on

kuuluvad Mandri-Euroopa ja Ladina-Ameerika maad, samuti Québeci provints Kanadas ja Louisiana osariik Ameerika Ühendriikides. Kontinentaalse õigussüsteemi elemente võib leida veel Šoti õiguses, Lõuna-Aafrika Vabariigis, Mauritiusel, Filipiinidel ja mujalgi. Angloameerika õigussüsteemi moodustavad Inglismaa (ka Wales), Ameerika Ühendriigid, Kanada, Austraalia ja Uus-Meremaa (Narits 1995: 46-47).

${ }^{5}$ Vrd ius commune: "Gemeines Recht (hervorgegangen aus der wissenschaftlichen Bearbeitung römisher und kanonisher Rechtsquellen und deren Anpassung an die deutschen Verhältnisse)" (Lieberwirth 1987); "Gemeines Recht. Recht, welches allgemein gilt. In der frühen Neuzeit wurde darunter das allgemein geltende römish-kanonische Recht verstanden" (Benke, Meissel 1997); "The common law" (Jowitt's Dictionary); "In the civil law, common right; the common and natural rule of right, as opposed to jus singulare. In English law, the common law, answering to the Saxon folcright" (Black 1998)

${ }^{6}$ Vrd exitus: "Tod" (Lieberwirth 1987); "Der Tod (wörtlich: Ausgang; Ende)" (Benke, Meissel 1997); "Issue or offspring; the yearly rents and profits of lands and tenements" (Jowitt's Dictionary); "Children; offspring. The rents, issues and profits of land and tenements. An export duty" (Black 1998).

7 Vrd breve: "Brief; Beweisurkunde; päpstliches Reskript in Briefform" (Lieberwirth 1987); "Im KirchenR: Kurzes päpstliches Schreiben" (Benke, Meissel 1997); "A writ by which a person is summoned or attached to answer an action, complaint, etc., or whereby anything is commanded to be done in the courts, in order to do justice, etc." (Jowitt's Dictionary); "A writ. An original writ or precept of the king issuing out of his courts. A writ by which a person was summoned or attached to answer an action, complaint, etc., or whereby anything was commanded to be done in the courts, in order to justice, etc." (Black 1998).

8 Kontinentaalses õigussüsteemis eristatakse õiguse perekondi, mis on põhimõtteliselt rajatud ühtsetele alustele - õigusnormidele -, kuid kus võib kohata ka erinevusi. Eristada võib romaani ja germaani õiguse perekondi. Nende õigusrühmade terminid suuremas osas kattuvad. Siiski võib ka leida väljendeid, mille tähendused ei lange osaliselt kokku või mõnel juhul erinevad isegi täielikult. Romaani perekonda kuuluvad Prantsusmaa, Belgia, Luksemburg, Monaco, Itaalia, Hispaania, Holland. osaliselt Ladina-Ameerika riigid, Québec Kanadas, endised Prantsusmaa kolooniad Aafrikas, Maroko, Tuneesia, Alžeeria, Liibanon, Süüria, endine Hollandi koloonia Indoneesia. Germaani perekonda kuuluvad Saksamaa Liitvabariik, Austria, Liechtenstein, Šveits, Türgi, Kreeka. Teatud reservatsioonidega võib siia paigutada ka Jaapani, Lõuna-Korea ja Tai. Kuni 1949. aastani kuulus siia perekonda Hiina RV. Germaani õiguse perekonnast ei asu kaugel viis Pöhjamaad: Soome, Rootsi, Norra, Taani ja Island. Eesti koht kontinentaalses õigussüsteemis on lähemal germaani perekonnale kui mõnele teisele struktuurile (Narits 1995: 46-47).

${ }_{9}$ Mandri-Euroopa õiguskultuuri on kujundanud eelkõige Rooma õiguse retseptsioon. 13.-16. sajandil levis Rooma õigus Ülem-Itaaliast üle kogu Euroopa. Selline kirjalikult fikseeritud ja dogmaatiliselt kommenteeritud õiguskord astus Euroopas sugukonnaõiguse kõrvale ja hakkas seda ka asendama. 19. sajandil süstematiseeriti retsepteeritud õigus põhjalikult ja nii kujunes Rooma õigusest üks tänapäevase Mandri-Euroopa õiguskultuuri põhialus. (Narits 1997: 5.) Kontinentaal-Euroopa õiguskultuur toetub peamiselt kahele arusaamisele õigusest: loomuõigusele ja positivismile. Kontinentaal-Euroopa õiguse sajanditepikkuse arengu tulemuseks on Euroopa üldise õiguse perekonna (ius commune) väljakujunemine. Sellesse õigusperekonda kuuluvates õigussüsteemides on sotsiaalsete normide seas esiplaanil õigusnormid, mis vastavad õigluse ja moraali nõuetele. Tavad kujutavad siin endast täiendust seadustele, need on abiks seaduse tõlgendamisel ja õiglaste otsuste langetamisel. Põhjalikumalt ius commune pärandi kohta vt Knütel 1994 ning Berman, Reid 1995: 3-34.

10 Germaani ja romaani õigusrühma tõlgete võrdlemisel on aluseks järgmised sõnastikud: Cornu 1992; Cabanellas, Alcalá-Zamora y Castillo 1992 ; Benke, Meissel 1997 ; Lieberwirth 1987; Liebs1998; Anners, Önnerfors 1972. 
selle termini tähendus kitsenenud: 'leping; hagi, hagi koostamine'. Termin pignus tähistab germaani õigusperekonnas panti, hüpoteeki, kuid romaani õigusperekonnas kasutatakse terminit tähenduses 'tõend'. Termin damnum on germaani õigusperekonnas 'kahju, trahv', romaani õigusperekonnas on termini tähendus laienenud ning see tähistab konfiskeerimist. Sõna consilium puhul erinevad tähendused ka ainult germaani õigusperekonna sõnastikes: ühes on tõlkeks märgitud 'nõukogu; nõupidamine (arstide nõupidamine haigusjuhtumi teemal)', teises aga lisatakse olulisi juriidilisi vasteid: 'kohtuniku otsus; kohtukolleegium'. ${ }^{11}$

Ladina terminite mitmetähenduslikkuse on põhjustanud ka nende väljakujunemine väga pika aja, rohkem kui kahe aastatuhande vältel. Aja jooksul on muutunud mõistete sisu. Näiteks väljendil ius civile ('tsiviilõigus') on arvukalt tähendusi. Rooma õiguses tähistas see ühelt poolt Rooma klassikalist õigust (vastandiks magistraatide praktikaga kujundatud ius honorarium), teiselt poolt Rooma kodanike suhteid reguleerivat õigust (vastandiks ius gentium 'rahvaste õigus') (Birks, McLeod 1987: 8-9).

Bütsantsis, keskaja Lääne-Euroopas ja veel uusajalgi märkis ius civile peamiselt Rooma õigust, laiemalt ka positiivset õigust, mis vastandus jumalikule õigusele (ius divinum) ning loomuõigusele (ius naturae). Keskajal hakkas välja kujunema ka ius civile kasutamine praeguses tähenduses. Nimelt keskendus keskajal õigusteadus Rooma õiguse tähtsaima, keiser Justinianuse korraldusel 6. sajandil koostatud koodeksi Corpus iuris civilis'e ('Tsiviilõiguse kogumik') nende osade uurimisele, mis puudutavad üksikisikute õigussuhteid. See mõjutas aja jooksul ka keelekasutust. Nii omandas termin 'tsiviilõigus' Euroopas oma praeguse tähenduse - üksikisikute vahelisi suhteid reguleeriv normide kogum (Roland, Boyer 1998: 240-241).

\section{2. Üksteisele lähedal seisvate mõistete tähistamine}

Sellesse rühma kuuluvad mitmetähenduslikud terminid, mis tähistavad üksteisele lähedal seisvaid mõisteid. Ladina keeles valmistavad suuremat mõistmisraskust ning vajavad enam täpsust tõlgendamisel sellised terminid, mis tähistavad ühelt poolt alist ehk objekti, teiselt poolt aga tegevust, protsessi toimumist ja selle tulemust. Tuntumad ja sageli kasutatavad on näiteks järgmised sõnad: hereditas ('pärand' ja 'pärimine'), possessio ('valdus' ja 'valdamine'), emptio ('ost' ja 'ostmine'), dominium ('omand'12 ja 'omamine').

Terminite mitmetähenduslikkus ei tekita alati olukorda, kus neid ei saaks õigesti mõista. Harilikult rõhutatakse, et termin ei vaja konteksti, on mõistetav kontekstitagi. Seda asjaolu ei tohi absolutiseerida. Täielikult avaneb termini sisu alles kaastekstis (Erelt 1982: 42).

Näiteks sõna hereditas väljendab objekti ning on tähenduses 'pärand' järgmistes väljendites: hereditas iacens 'lamav pärand'13, acquisitio hereditatis 'pärandi vastuvõtmine', hereditas, alia corporalis, alia incorporalis; corporalis est, quae tangi potest et videri; incorporalis, quae tangi non potest nec videri 'pärand on kas kehaline või kehatu; kehaline on see, mida saab katsuda ja näha, kehatut katsuda ega näha ei saa'. Seevastu tegevust või protsessi tähenduses 'pärimine' väljendab fraas: hereditas est successio in universum, quod defunctus habuit 'pärimine on kõigi õiguste ülekandumine, mis oli surnule kuulunud'.

11 Vrd collegium: "Rat, Beratung (von Ärzten über einen Krankheitsfall)" (Bruss 1999); "Rat; Richterspruch; Richter-

12 Terminit dominium on varemalt eesti keelde tõlgitud ka sõnaga isandus (analoogia dominus 'isand') (Talvik 1936:

${ }^{13}$ Rooma õiguses pärandi nimetus ajavahemikul pärandi avanemisest kuni selle vastuvõtmiseni (Adomeit jt 2005). 
Lähedalseisvaid mõisteid tähistavate terminite mitmetähenduslikkust peetakse oskuskeelt häirivaks nähtuseks ning soovitatakse sellest võimaluse korral hoiduda (Erelt 1982: 40-41; Mõttus 1997: 37). Näiteks võib siia tuua eestikeelsete terminite omand, omandus ja omandiõigus tähendusliku vahekorra ja nende kasutuse oskuskeeles, mis leidis laialdast kajastamist pärast asjaõigusseaduse (1993) vastuvõtmist. Asjaõigusseaduses on kasutatud terminit omand omandiõiguse tähenduses. Üldkeeles ja laiemalt õiguskeeles käsitatakse omandit üksnes omandiõiguse esemena. Asjaõigusseaduse kohaselt võib asi olla kellegi omandis, üld- ja õiguskeele kohaselt kellegi omanduses. ${ }^{14}$

\section{Ladina õigusterminite sünonüümia}

Üks kesksemaid terminikorrastusprobleeme on terminoloogia variatiivsuse küsimus, oskussõnade variantide, sünonüümide probleem lähemalt vt Saari 1980a, 1980b, 1981a, 1981b).

Varem valdava seisukoha asemel, et igale mõistele vastaku üksainus kindel terminikuju, on viimastel aastakümnetel jõutud arusaamisele, et variante terminoloogias vältida ei saa, kuid need on vaja allutada teadlikule korrastatusele. ${ }^{15}$ Variantide esinemist taunitakse põhjusel, et erinevad terminivariandid koormavad mälu. Tähtsamaks tuleb pidada siiski sisulisi põhjuseid, s.t sünonüümia annab võimaluse kõrvaltähenduste tekkele, hägustab arusaamist, n-ö “terminimüra” (Erelt 1982: 45). Sünonüümide kasutamisel on seega oht, et eri sõnakujudesse hakatakse panema eri sisu, nii et täissünonüümid muutuvad ajapikku osalisteks sünonüümideks ja omandavad kõik mitmetähendusliku termini pahed. Seetõttu tuleb hoiduda sünonüümide tähenduse hargnemisest (Saari 1980a: 660; Saari 1980b: 738).

Teaduskirjanduses, terminisõnastikes ning mujal on sünonüümid siiski paratamatud (Saari 1980a: 660), seetõttu peetakse ka korrastatud terminoloogias vajalikuks lubatavat sünonüümiat, terminivariantsust (Kull 200ob: 3). ${ }^{16}$ Sünonüümide lubatavus terminoloogias tagab väljenduskvaliteedi, eelkõige stiili ladususe ja paraja vahelduslikkuse.

Õiguskeele uurimused näitavad, et juriidilises terminoloogias on sünonüümid laialt levinud (Mattila 2002a: 177-178). Teistes keeltes peale romaani keelte võib sama mõistet väljendada tihti nii ladinatüveline võõrsõna kui ka omasõna. ${ }^{17}$

Ladina õigusterminite puhul on märkimisväärne, et variandid ei erine õiguskultuuriti ega keelepiiride tasandil. Ladina terminite variantsus esineb võrdselt nii sama keele piires kui erinevate keelte raames, kui käsitletakse sama teemat.

Sünonüümsus on enamasti kahe sõna vahel, kuid see võib esineda ka sõna ja ühendi vahel, millest esimene on toimingut või selle vahendit näitav substantiiv ja teine teonimi (gerundium). Viimane täpsustab lühemat ja kompaktsemat varianti, näiteks ususfructus ja ius utendi-fruendi ('kasutusvaldus'), aquaeductus ja ius

\footnotetext{
14 Selle temaatika kohta vt lähemalt Ekspertarvamus 1995; Kull 2000a: 124-127; Mereste 1995: 35-38; Mereste 2000: 338-356; Kask, Kull 1996: 19-27; Pärna 1995: 27-28.

${ }^{15}$ Vt nt Kull 2000a: 101, Kerge 2004: 33-34, Saari 1980a: 657-663, Erelt 1982: 44-51. Siiski on põhimõte “ühele terminile lähtekeeles peab vastama üks konkreetne termin tulemkeeles" aluseks veel näiteks tänases Läti terminoloogiatöös (Tavast 2004: 11).

${ }^{16}$ Lubatud ja soovitatava sünonüümia peamised liigid on: omasõna-võõrsõna paarid, põhitermin koos argivariantidega, keelepragmaatikast ja kontekstist tingitud muudatused ning üleminekud motiveeritud väljendilt arbitraarsele. Lubatud variantsuse kohta terminoloogias vt Kull, Saari 1975

25817 Inglise õiguskeeles on näiteks levinud sõnakordus, milles sõnapaari üks sõna on moodustatud ladina-romaani tüvest ning teine germaani tüvest: acknowledge and confess, will and testament. Selline binaarsus kujunes välja perioodil, kui Inglismaa õiguskeelteks olid ladina ja prantsuse keel ning anglosaksi terminite kõrval võeti kasutusele ladina-prantsuse variandid. Kordused aitasid kergemini mõista terminite tähendust; tänapäeval kinnitab samatähenduslike sönade kordamine, et kogu soovitud semantiline väli on kaetud. Sõnakordus on nähtus, mis levib eriti teadusharu kujunemisjärgus (Tiersma 1999: 100-101; Mellinkoff 1963: 74-75). Oma- ja võõrsõna paaride kohta vt ka alapeatükk 2.1.2.
} 
aquam ducendi ('veejuhtimise õigus'), iter ja ius eundi ('läbimineku ehk käigutee õigus').

Samuti võivad sünonüümid olla ühendid või mitmesõnalised väljendid omavahel. Siinjuures võivad sünonüümideks olla nimisõnaühendi põhisõnad, näiteks servitutes praediorum ja iura praediorum ('prediaalservituudid'), servitutes personarum ja iura personarum ('personaalservituudid'); täiendsõnad, näiteks causa capitis ja causa criminalis ('kriminaalprotsess'), culpa lata ja culpa magna ('raske hooletus'); aga ka väljendi tegusõnad, näiteks maius includit minus ja maius continet minus ('suurem hõlmab vähemat').

Sünonüüme võib jagada leksikaalseteks, grammatilisteks, ortograafilisteks ja lühivariantideks (Saari 1980a: 654-666 ja Erelt 1982: 46-47 eeskujul).

\subsection{Leksikaalsed variandid}

\subsubsection{Eri lekseemid}

Sellesse rühma kuuluvad sünonüümid juhul, kui iga ladinakeelne terminivariant kujutab endast eri lekseemi. Sellised sünonüümid ei ole ladina õigustekstides sagedased. Peamise hulga moodustavad ladina terminoloogias grammatilised, ortograafilised või lühivariandid. Siiski on mitmetel leksikaalsetel terminivariantidel nende tähenduse tõttu õigusmaterjalides oluline koht, eriti näiteks terminid dominium ja proprietas ('omand'). Eri lekseemidena võib leida veel järgmisi termineid: delictum ja maleficium ('õigusrikkumine'), mos ja consuetudo ('tava'), ascendentes ja linea superior ('ülenevas joones sugulus, ülenejad sugulased'), descendentes ja linea inferior ('alanevas joones sugulus, alanejad sugulased').

\subsubsection{Oma- ja võõrsõna paarid}

Sõnade päritolu järgi jagades on leksikaalsete variantide kõige levinum alaliik omaja võõrtermini paralleelne esinemine (Erelt 1982: 47). Oma- ja võõrsõna paarid on Rein Kulli ja Henn Saari käsitluse järgi oskuskeele lubatud ja soovitatava sünonüümia liik. Sünonüümide täielik vältimine saab toimuda ainult väljenduskvaliteedi arvel. Samas on tähtis, et säiliks oskuskeelse väljenduse ühtsus ja ühemõttelisus: "Üksühesed sõnade ja ühendite vastavused eri keelte vahel on isegi terminoloogias võimalikud üksnes piiratud ulatuses ja nimelt seda vähemas, mida enam keeled teineteisest erinevad.” (Kull, Saari 1975: 247-248).

Tuleb pidada loomulikuks, et ühe eriala oskussõnavaras on nii oma- kui ka võõrtermineid ja ka mõlemaid paralleelselt (Erelt 1982: 73). Nii esinevad eesti õiguskeeles omaterminid, ladina keelest tuletatud võõrterminid, oma- ja võõrsõna paarid ning liitsõnad ja sõnaühendid, milles oma-ja võõrmorfeemid on sulandunud üheks keelendiks. 


\section{- Eesti omasõnad õiguskeele terminitena}

Suurem osa eesti õiguskeele põhisõnavarast on loodud eesti omasõnavara põhjal, vähemal määral on kasutatud otselaene suurematest indoeuroopa keeltest (Soosaar 2005: 111, 117). Nii ei ole paljude eesti juriidiliste põhiterminite juures näha ladina tüvesid, pigem on need kujunenud omasõnadest või on omakorda nende põhjal loodud tuletised, näiteks õigus (vrd ladina ius), seadus (lex), tava (mos), karistus (poena), asi (res), sü̈̈ (culpa), leping (contractus), kohtunik (iudex) jpt.

Mida üldisema tähendusega on termin ja mida laiemat hulka inimesi see praktikas puudutab, seda õigustatum on omatermini kasutamine. Ja vastupidi, mida spetsiifilisemaks läheb termini sisu, seda rohkem tuleb kasutusele võõrtermineid.

Omakeelsete oskussõnade talitlusviisid üldjuhul erinevad võõrterminite omast. Kuna omaterminid on juurdunud just omakeelsetena, siis on need enamasti selgemad, läbipaistvamad ning seega ka üldarusaadavamad ja täpsusvõimelisemad. Omasõnalised keelendid kõnelevad nii spetsialistidele kui ka mittespetsialistidele, seega avaralt ühe keele kasutajate piires. Avalikkusega suhtlemisel (nt seaduskeeles jm) soovitataksegi eelistada rohkem omakeelseid oskussõnu, jättes võõrsõnalisema kasutuse spetsialistide omavahelisse suhtlusse (Kull 2000c: 551; Erelt 1982: 73; Saari 1981a: 209).

\section{- Ladina päritolu sõnad õiguskeele terminitena}

Erialaterminoloogia üheks loomise ja rikastamise allikaks on sõnade laenamine teistest keeltest; teadusalati võib laenamise intensiivsus perioodide lõikes erineda (Lill 1986: 77). Eesti oiiguskeeles on kasutusel palju ladina sõnadest tulenevaid termineid, mis pärinevad Rooma õigusest. Rooma õigusest pärit termineid on eriti rohkesti tsiviilõiguses ja peamiselt selle võlaõiguse osas (Ilus 2000: 15). Nii tugevalt juurdunud võõrterminite puhul ei pea ka keelekorraldajad vajalikuks otsida ja juurutada omakeelseid vasteid. Nende kasutuse poolt räägib samuti rahvusvaheline tuntus ja levik (Vettik 1996: 5; Erelt 1982: 74). Enamasti tähistavad sellised terminid mõisteid, mis vajaksid oma keeles pikki, sageli mitmest lausest koosnevaid seletusi. Eesti õiguskirjandusest võib leida näiteks järgmisi võõrtermineid: testament (vrd ladina sõna testamentum), regress (regressus), advokaat (advocatus), eviktsioon (evictio), subjekt (subiectum), kodifitseerimine (codificatio), bilateraalne (bilateralis), kautelaarjurisprudents (cautelaris + iurisprudentia), tsiviilprotsess (civilis + processus).

Mitmed loetletud võõrterminitest on tihti kasutusel ka eesti üldkeeles ning mõjuvad tekstis hariliku ja sisuselgena. Enamik neist tähistab aga väga spetsiifilisi mõisteid, olles arusaadavad vaid õigusteadlaste ringile. Kui omakeelsed terminid on eelistatumad omakeelse avalikkusega suhtlemisel, siis ladinatüvelised võõrterminid, mis on levinud nii angloameerika kui ka Mandri-Euroopa õigussüsteemide oskuskeeltes, soodustavad õigusteadlaste rahvusvahelist suhtlemist. Seega võib ka öelda, et üldiselt hõlbustavad stiili poolest neutraalsed võõrsõnalised keelendid suhtlemist teiste keelte kasutajatega.

\section{- Võõr-ja omaterminite paralleelne kasutamine}

Kõige sagedamini võib eesti õigustekstidest leida võõr-ja omaterminite paare, mida kasutatakse erialakeeles koos, näiteks õigusrikkumine ja delikt (ladina delictum), seaduslik ja legaalne (legalis), võlasuhe ja obligatsioon (obligatio), seadustik ja koodeks (codex), õiguslik ja jurïidiline (iuridicus). 
Oma- ja võõrsõna paaride võrdlemisel võib näha, et vahel võib võõrsõna olla tavapärasem, vahel vastupidi. Sellistel variantidel võib olla erisugune väljendusväärtus ja stiilivärv. Omakeelend on sageli, kuid mitte alati, täpsem või diferentseerivam. Seda juhul, kui omatermin on spetsiaalselt eriala jaoks loodud, üldkeelest võetud omaterminite puhul seda öelda ei saa. Oluline põhjus on see, et omaterminid ei sõltu võõrsõnade kirjust ajaloost, homonüümiast, polüseemiast ja korraldamatusest. Samas on raske mõõta omasõna jutustavust, sest palju oleneb iga konkreetse inimese emakeele- ja võõrkeelteoskusest, aineala ja võõrsõnaelementide tundmisest (Saari 1981b: 285).

Võõrsõna-omasõna variantsuse korral tuleb arvestada suhtlussituatsiooni ja teksti suunitlust. Üldiselt on suurem võõrsõnakasutus omane kitsamalt erialasele käsitlusele, eriti rahvusvahelises infovahetuses ja keeltevahelises suhtluses, omakeelendite eelistamine on omal kohal aga omakeelse ja üldisema esituse korral. Võõrsõnadele on omane ekso- ehk väljapoole-, omasõnadele aga endo- ehk sissepoolesuunitlus (Kull 2000a: 113; vt ka Kull 2000c: 550-551; Vettik 1996: 5). Võõra ja oma termini kasutamisel tuleb samuti arvestada oma oskussõnavara lähedust teiste rahvaste terminoloogiale ning oskuskeele kokkukuuluvust rahvuskeelega (Erelt 1982: 76).

Eesti õigustekstides (nt ajakirjas Juridica ja õppematerjalides) rakendatakse enamasti stiilivahelduse huvides korraga mõlemat paarikut, s.o nii võõrsõnalist kui ka omasõnalist väljendit. Siiski viitavad õiguskeele uurijad, et üldjuhul eelistatakse juristide kirjatöödes terminite sünonüümse kasutuse puhul võõrsõna (Kukk 2003: 100).

\section{- Liitsõnad ja sõnaühendid}

Peale kõrvu esinemise ning tekstis vaheldumise avaldub oma ja võõra keeleainese kooseksistents ka selles, et oma- ja võõrmorfeeme võib sulatada kokku üheks keelendiks, moodustada nn hübriide. Võõr- ja omasõnadest moodustatud liitsõnade ja sõnaühendite moodustamise otstarbekuse määrab nagu võõrterminitegi puhul mõiste tarvitamise ulatus.

Sageli võib tekstidest leida liitsõnu, milles põhisõnaks on omasõna, täiendosaks võõrtüvi. Omasõna vaatenurgast on see progressiivne liitumine, näiteks apellatsioonkaebus (ladina apellatio), regressiõigus (regressus), tsiviilõigus, tsiviilasi, tsiviilisik (civilis), munitsipaalõigus (municipalis), kausaaltehing (causalis), krediidileping (creditum), agendileping (agens), komisjonileping (commissio).

Liitsõnad võivad esineda ka vastupidisel kujul, seega regressiivse liitumisena, kus põhisõnaks on võõras tüvi, näiteks õigusnorm (ladina norma), õigusobjekt (obiectum), kohtuinstants (instans < instantia keskaegne tähendus), õigusinstituut (institutum), eraldamisprintsiip (principium). Sellistes liitsõnades ei ole ladina sõnad spetsiifiliselt õigusteaduse alale kuuluvad mõisted.

Samuti on õigustekstides sagedased sõnaühendid, mille moodustavad omasõna ja võõrsõna. Ladina tüvest tuletatud võõrsõna on enamasti täiendiks, seega täpsustavaks mõisteks: bilateraalne leping (ladina sõna bilateralis), negatoorne hagi (negatorius), reaalsed lepingud (realis), singulaarne õigusjärglus (singularis), formaalne karistusõigus (formalis), jurïdiline isik (iuridicus), intellektuaalne omand (intellectualis), sotsiaalne kaitse (socialis), primaarsed allikad (primus), subjektiivne õigus (subiectivus), faktiline võim (factum).

Nendes näidetes leidub ka juhtumeid, kus võõrkeelest pärit sõna võiks edukalt asendada omasõna, näiteks faktiline võim tegelik võim (factum 'tegu'). Samuti 
leidub õiguskeeles ka väljendeid, milles ladinatüveline võõrtermin on sõnaühendis põhisõnaks, näiteks isiklik servituut (servitus), õiguse kodifitseerimine (codificatio), avalik-õiguslik korporatsioon (corporatio).

\subsection{Grammatilised variandid}

Ladina õigusterminoloogias on laialt levinud sünonüümide grammatilised variandid. Need on ladina keele eripärast (tuletusviis, grammatiline süsteem) tulenevad terminivariandid, mille sõnatüved langevad täielikult või osaliselt kokku, erinev on üksnes nende grammatiline vormistus.

Sünonüümseteks terminiteks võivad olla näiteks grammatilised vormid ja tuletised. Paljudel juhtudel moodustatakse variant passiivi partitsiibi tüvele liidetud tegevuse toimumist või selle tulemust väljendava sufiksiga -(t)io, näiteks locatum ja locatio ('üür, üürimine'), emptum ja emptio ('ost, ostmine'), venditum ja venditio ('müük, müümine'). Grammatilised sünonüümid võivad lähtuda ka omadust väljendava sufiksi -tas ning päritolu väljendava liite -inus kasutamisest, näiteks aequum ja aequitas ('võrdsus'), libertus ja libertinus ('vabakslastu'). Siin on tegu substantiveerunud adjektiivide ja adjektiividest tuletusliite abil saadud substantiivide paralleelse esinemisega.

Terminivariante esineb samuti samast sõnatüvest moodustatud omadussõnalise ja nimisõnalise (genitiivi käändes või koos eessõnaga) täiendiga, näiteks ius naturale ja ius naturae ('loomuõigus' ${ }^{18}$ ), successio universalis ja successio per universitatem ('üldõigusjärglus'), actio doli ja actio de dolo ('salakavaluse kohta esitatud hagi'). Eestikeelsete vastete puhul siin variatiivsust pole.

Sünonüümid tekivad ka verbi kõneviiside (indicativus, coniunctivus, imperativus), eituspartiklite, samuti oleviku ja minevikuaegade varieerimisel: ne bis in idem ja non bis in idem ('ärgu olgu / mitte kaks korda sama asja eest'), nemo plus iuris ad alium transferre potest quam ipse habet ja nemo plus iuris ad alium transferre posset quam ipse haberet ('mitte keegi ei saa rohkem õigusi teisele isikule üle kanda, kui tal endal on / võiks olla'), audiatur et altera pars ja audi alteram partem ('võetagu kuulda / kuula ka teist osapoolt'), iura novit curia ja iura noscit curia ('kohus tundis/tunneb õigust').

\subsection{Ortograafilised variandid}

Kõige rohkem võib õigustekstidest leida ladina terminite ortograafilisi variante. Need on sünonüümid, mille terminivariantide erinevus kajastub ainult õigekirjas. Ortograafilised variandid võivad tekkida ladina õigusterminoloogiasse võõrsõnade (enamasti kreeka keelest, aga ka teistest keeltest) laenamisel, kus mõjuvad kaasa ladina keele enda fonoloogilised seaduspärasused ja häälikuline eripära, näiteks aspiraatide vähesus: thesaurus ja tesaurus ('peitvara'), hypotheca ja hypoteca ('kinnis(asja)pant'), arrha ja arra ('käsiraha'). Variante moodustavad ka liitsõnad, milles eesliite ja põhisõna ühinemisel on toimunud häälikumuutus. Need variandid on tingitud keelearengu üldisest seaduspärast (assimilatsiooniprotsessid, geminaadi lühenemine jne): adquisito ja acquisitio ('omandamine'), adscriptio ja ascriptio ('allkiri'), connubium ja conubium ('abielu'), exsilium ja exilium ('pagendamine').

${ }^{18}$ Vrd ius naturale / ius naturae varasemat eesti vastet loodusõigus. 
Ortograafilisi variante annab veel -cija -ti vaheldumine ladina terminites, põhjuseks antiikaja lõpus toimunud häälikuühendi -ti- assibilatsioon: condicio ja conditio ('tingimus'), nuncius ja nuntius ('advokaat; esindaja'), actio pigneraticia ja actio pigneratitia ('pandinõue').

Variante tekib samuti kokku- ja lahkukirjutamisel, näiteks ius iurandum ja iusiurandum ('vanne'), iuris prudentia ja iurisprudentia ('õigusteadus'), senatus consultum ja senatusconsultum ('senati otsus'), sub poena ja subpoena ('karistuse ähvardusel'). Kokku- ja lahkukirjutamine ei anna siiski mitte alati samatähenduslikku vastet. Näiteks erineb tähendus järgmiste terminite puhul: $a b$ usu '(tavakohaselt') ja abusu ('kuritarvitades').

Mitmetes väljendites on variatiivsuse põhjustajaks sõnajärg, näiteks ratio scripta ja scripta ratio ('kirjapandud tarkus'19), sensu stricto ja stricto sensu ('otseses mõttes'), actor forum rei sequitur ja actor sequitur forum rei ('hageja kuuletub kostja elukohamaa kohtule'), de minimis lex non curat ja de minimis non curat lex ('seadus ei kanna hoolt kõige tühisemate asjade eest'). Ladina keeles on sõnajärg suhteliselt vaba. Üldjuhul paikneb täiend põhisõna järel. Siiski ei muuda täiendi ja põhisõna ümberpaigutamine väljendi tähendust. Eesti keeles on sõnajärje puhul iseloomulik, et öeldisverb püsib tekstilauses teisel kohal (Kerge 2001: 155). Ladina keeles paikneb öeldis enamasti lause lõpus, kuid toodud näidetes jääb lause tähendus samaks ka juhul, kui öeldise koht on variandis muutunud.

\subsection{Lühivariandid}

Ladina õigusterminite täisvariantide kõrval kasutatakse ka lühivariante. Terminite lühivariandid saadakse termini komponentide asendamise või väljajätmise ehk ellipsi teel.

\subsubsection{Asendamine}

Asendamine toimub, kui terminis on sõnaühendid asendatud ühe nimisõnaga, mis kujutab endast ühendis esineva sõna grammatilist ja tuletuslikku varianti. Sellistes lühivariantides jäetakse ära põhisõna, täiendsõnast saab iseseisev substantiiv, näiteks ius utendi-fruendi ja ususfructus ('kasutusvaldus'), res mobiles ja mobilia ('vallasasjad'), lex loci regit actum ja locus regit actum ('koha seadus / koht juhib tehingut' ${ }^{\prime 2}$ ), actori incumbit onus probandi ja actori incumbit probatio ('hagejal lasub tõendamiskoormis / tõendamine'). Väljendi võib asendada ka uue nimisõnaga, näiteks praescriptio longi temporis ja usucapio ('igamine').

\subsubsection{Ellips}

Elliptiline variant saadakse terminist ühe või mitme komponendi väljajätmisel. Paljudel juhtudel jäävad välja verbi erinevates vormides osised (infinitiiv, partitsiip, gerundiiv), näiteks pacta sunt servanda ja pacta servanda ('lepingud tuleb täita'), ex post facto ja ex post ('pärast jõustumist toimuv'), lex loci delicti commissi ja lex loci delicti ('kuritöö toimepanemise koha seadus'), suum cuique tribuere ja suum cuique ('määrama igaühele oma'). Termini lühivariante moodustatakse ka nimisõnade väljajätmisega: legitimatio ad causam activa ja legitimatio activa ('aktiivne

19 Väljendit kasutatakse Rooma õiguse, eriti Corpus luris Civilis'e kohta (Adomeit 2005)

\footnotetext{
${ }^{20}$ Tehingu tegemisel kehtib selle maa seadus, kus tehing tehti (Adomeit jt 2005).
} 
legitimatsioon'), lex specialis derogat legi generali ja lex specialis derogat generali ('eriseadus tühistab üldise seaduse'). Samuti leidub elliptilisi variante, milles jäävad välja nii verb kui substantiiv: de cuius hereditate agitur ja de cuius ('kelle pärand on arutlusel').

Angloameerika õigusterminoloogias leidub palju väljendeid, mis sisaldavad ladina sõnade kõrval ingliskeelseid sõnu, näiteks ad hoc agreement, eiusdem generis rule, ex parte proceeding, in personam jurisdiction. Mõnikord võib sellises väljendis esineda ka ladina termini elliptiline vorm, mida ei ole võimalik avada sõnade põhitähenduse kaudu. Näiteks terminis nisi prius clause on vanast ladinakeelsest väljendist kasutatud vaid paari esimest sõna, mille tõlge 'kui mitte varem' ei viita termini võimalikule tähendusele. Sõnastiku järgi hakkas see väljend keskaegsel Inglismaal tähistama olukorda, kus vandemeestel kästi tulla Londonisse Westminsterisse, "kui mitte varem" polnud kohtupidamist korraldatud maakonnas. Tänases angloameerika õiguskeeles tähistab see termin esimese astme menetlust vandemeeste juuresolekul (Sodhi, Vasan1980: 57).

\section{Kokkuvõte}

Oskuskeel kui täpsete erialamõistetega opereeriv keelevariant esitab keelenditele kui nimetusüksustele teised nõuded kui üldkeel. Terminoloogia puhul on vajalik sisuline, mõisteline täpsus, s.t sellised eristused ja täpsustused, mis üldkeelele pole nii rangelt vajalikud ega omased. Oskuskeeles välditakse üldiselt nii terminite mitmetähenduslikkust kui samatähenduslikke termineid, kuid täielikult neist hoiduda ei saa. Terminite tegelikud talitlustingimused loovad tüüpsituatsioone, kus tähistaja ja tähistatava üksühese vastavuse rikkumine on paratamatu: terminit keelemärgina mõjutavad polüseemia ja sünonüümia.

Terminite mitmetähenduslikkust ehk polüseemiat oskuskeeles üldiselt välditakse. Absoluutne ühetähenduslikkus pole siiski kooskõlas keele funktsioneerimise põhialustega. Termini sisu vastab kohas ja ajas kehtivatele seaduspärasustele, selle kasutus võib kitseneda, laieneda või nihkuda teiste mõistete suunas. Mitmetähenduslikkuse puhul eristuvad kõigepealt termini tähendused üldkeeles ja õiguskeeles. Polüseemiat esineb ka õiguse valdkondade vahel. Erinevad tähendused samadele terminitele on kujunenud näiteks karistusõiguses ja tsiviilõiguses.

Õigusterminite tähendused erinevad ka suurte õigussüsteemide keelekasutuses. Õiguskeel erineb teistest erialakeeltest olulises aspektis: see on kultuuripõhine ning seotud ühe kindla ühiskonna ja selle õigussüsteemiga. Ehkki Euroopa õigusmõtlemine baseerub ühisel Rooma õiguse pärandil ning sellest võrsunud terminid on õigussüsteemides juurdunud, erinevad paljude ladina väljendite tähendused angloameerika ja Mandri-Euroopa õigussüsteemide terminoloogias. Väiksemaid lahknevusi terminite tähenduses võib leida ka Mandri-Euroopa õigussüsteemi romaani ja germaani õigusperekondade keelekasutuses.

Õiguskeeles on levinud ka sünonüümid ehk terminivariandid. Ehkki erialasel terminikasutusel on omad nõuded ja erijooned võrreldes keele üldsõnavaraga ning terminite kasutusega väljaspool erialast tarvitust, on siin ka kokkupuutepunkte ning sarnaseid jooni. Neid esineb niihästi leksikaalsete kui ka muude variantide kasutamises. Oskuskeeles ei ole terminiteisendused nii vabalt kasutatavad kui üldkeeles, siiski ei saa õigusterminoloogias variante täielikult vältida. 
Ladina keelest pärit õigusterminite puhul ei erine variandid õiguskultuuriti ega keelepiiride tasandil. Sünonüümsus on enamasti kahe sõna vahel, kuid see võib esineda ka sõna ja ühendi vahel, kusjuures viimane täpsustab lühemat ja kompaktsemat varianti. Samuti võivad sünonüümid olla ühendid või väljendid omavahel. Sagedased on terminite grammatilised ja ortograafilised variandid, samuti täistermini ja selle lühikuju paralleelne esinemine. Leksikaalsete variantide levinuim liik on võõrsõnalise ja omakeelse termini rööpesinemine. Suurem võõrsõnakasutus on omane erialasemale keelekasutusele, eriti rahvusvahelises infovahetuses ja keeltevahelises suhtluses, omakeelendite eelistamine on omal kohal aga omakeelse ja üldisema esituse korral.

\section{Kirjandus}

Adomeit, Klaus; Ristikivi, Merike; Siimets-Gross, Hesi 2005. Ladina-eesti õigussõnastik. Peeter Kask (toim.). Tallinn: Eesti Keele Sihtasutus.

Anepaio, Toomas; Hussar, Ave; Jaanimägi, Katri; Kaugia, Silvia; Land, Kristi; Olle, Vallo; Roosma, Peeter 2005. Sissejuhatus õigusteadusesse. Tallinn: Juura.

Anners, Erik; Önnerfors, Alf 1972. Latinsk juridisk terminologi. Uppsala: Juridiska Föreningen i Uppsala.

Asjaõigusseadus 1993. Vastu võetud 9.06.1993. a seadusega (RT I 1993, 39, 590), jõustunud 1.12.1993.

Benke, Nikolaus; Meissel, Franz Stefan 1997. Juristenlatein. Lateinische Fachausdrücke und Redewendungen der Juristensprache, übersetzt und erläutert. Wien: Juridica.

Berman, Harold J.; Reid, C. Jr. 1995. Römisches Recht in Europa und das ius commune. Zeitschrift für europäisches Recht, 3-34.

Berteloot, Pascale 1999. Der Rahmen juristischer Übersetzungen. - Recht und Übersetzen. Hrsg. Gerard Rene de Groot, Reiner Schulze. Baden-Baden: Nomos.

Birks, Peter; McLeod, G. 1987. Justinian's Institutes. London: Gerald Duckworth \& Co.

Black, Henry Campbell 1998. Black's Law Dictionary. 13th reprint, 6th ed. by the publisher's editorial staff. Coauthors Joseph R. Nolan, Jacqueline M. Nolan-Haley. Contributing authors M. J. Connolly et al. St. Paul, Minnesota: West Publishing Co.

Bruss, Jochen 1999. Lateinische Rechtsbegriffe. 2. Aufl. Freiburg: Haufe Verlagsgruppe.

Cabanellas, Guillermo; Alcalá-Zamora y Castillo, Luis 1992. Diccionario enciclopédico de derecho usual I-VIII. 16a ed. Buenos Aires: Editorial Heliasta.

Cornu, Gerard 1990. Linguistique juridique. Paris: Montchrestien.

Cornu, Gerard 1992. Vocabulaire juridique. Paris: Presses Universitaires de France.

Ekspertarvamus 1995 = Sõnade omand ja omandus semantika ning terminoloogiline rakendatavus. Eesti Keele Instituudi ekspertarvamus. 1995. - Õiguskeel 2, 24-26.

Erelt, Tiiu 1982. Eesti oskuskeel. Tallinn: Valgus.

Ilus, Elmar 2000. Rooma eraõiguse alused. Heiki Pisuke (toim.). Tallinn: Ilo.

Jowitt's Dictionary = Jowitt's Dictionary of English Law I-II. 1977. London: Sweet \& Maxwell.

Kask, Peeter; Kull, Rein 1996. Asjaõigusseaduse terminikasutus. - Õiguskeel 5, 19-27.

Kerge, Krista 2001. Eesti süntaks keeleõppe praktikule. Käsiraamat. Tallinn: TEA Kirjastus.

Kerge, Krista 2004. Terminid leksikaalse ja grammatilise keelendina. - Sirje. Mäearu (toim.). Rahvusvaheline terminoloogiakonverents "Eesti oskuskeel 2003" 10. ja 11. oktoobril 2003. Ettekanded. Tallinn: Eesti Keele Sihtasutus, 19-46.

Knütel, Rolf 1994. Rechtseinheit in Europa und römisches Recht. - Zeitschrift für europäisches Recht, 244-276.

Kukk, Inga 2003. Õiguse ja halduse keel. - Maire Raadik (toim.). Eesti kirjakeele kasutusvaldkondade seisundi uuringud. Tallinna Pedagoogikaülikooli eesti filoloogia osakonna toimetised 4. Tallinn: TPÜ Kirjastus, 96-117.

Kull, Rein 2000a. Kirjakeel, oskuskeel ja üldkeel. Tallinn: Eesti Keele Sihtasutus. 
Kull, Rein 200ob. Kas kindel või lagundatud kirjakeel? (Muutuv keel) - Keel ja Kirjandus 1, $1-9$.

Kull, Rein 2000c. Oskuskeel ja üldkeel: erisused ja samasused. - Keel ja Kirjandus 8, 545-557.

Kull, Rein; Saari, Henn 1975. Die Entwicklung des estnischen terminologischen Gedankens und die Förderung der Fachsprachen in den letzten Jahren. - Congressus Tertius Internationalis Fenno-Ugristarum. Pars I. Acta Linguistica. Tallinn, 245-249.

Lieberwirth, Rolf 1987. Lateinische Fachausdrücke im Recht. Heidelberg: Müller.

Liebs, Detlef 1998. Lateinische Rechtsregeln und Rechtssprichwörter. 6. Aufl. München: Beck.

Lill, Anne 1986. Kreeka-ladina päritoluga terminite tulek Eesti meditsiinitekstidesse (18691914). - Tartu Riikliku Ülikooli Toimetised 728. Fenno-Ugristica 13, 77-88.

Mattila, Heikki E. S. 2002. Vertaileva oikeuslingvistiikka. Helsinki: Kauppakaari Lakimiesliiton Kustannus.

Mellinkoff, David 1963. The Language of the Law. Boston, Toronto: Little, Brown and Co.

Mereste, Uno 1995. Arvamus sõnade omand ja omandus semantikast ning rakendatavusest. Eesti Keele Instituudi ekspertarvamuse teemal. - Õiguskeel 3, 35-38.

Mereste, Uno 2000. Oskuskeel ja seaduste keeleline rüü. Tallinn: Eesti Keele Sihtasutus.

Mõttus, Aaro 1997. Seaduse sõnastamine ja terminoloogia (3). - Õiguskeel 4, 34-46.

Narits, Raul 1995. Õiguse entsüklopeedia. Õpik Tartu Ülikooli õigusteaduskonna üliõpilastele. Tallinn: Juura.

Narits, Raul 1997. Õigusteaduse metodoloogia I. Tallinn: Juura.

Oksaar, Els 1999. Kõnekeel, erialakeel, õiguskeel. - Juridica 4, 199-207.

Pärna, Priidu 1995. OMAND ja OMANDUS juriidilisest vaatekohast. - Õiguskeel 2, 27-28.

Ristikivi, Merike 2006. Ladina päritolu juriidilised terminid Eesti õiguskeeles. Magistritöö Tartu Ülikooli Raamatukogus.

Roland, Henri; Boyer, Laurent 1998. Locutions latines du droit français. Paris: Litec.

Saari, Henn 1980a. Omasõna ja võõrsõna paarid eesti oskussõnavaras (1). - Keel ja Kirjandus $11,654-666$.

Saari, Henn 1980b. Omasõna ja võõrsõna paarid eesti oskussõnavaras (1). - Keel ja Kirjandus $12,737-743$.

Saari, Henn 1981a. Omasõna ja võõrsõna paarid eesti oskussõnavaras (2). - Keel ja Kirjandus 4, 201-210.

Saari, Henn 1981b. Omasõna ja võõrsõna paarid eesti oskussõnavaras (2). - Keel ja Kirjandus $5,282-288$.

Silvet, Erki 1997. Ladinakeelne väljend õiguskeeles. - Õiguskeel 2, 16-19.

Sodhi, Datinder; Vasan, R. S. (Eds.) 1980. Latin Words and Phrases for Lawyers. New York: Law and Business Publications.

Soosaar, Sven-Erik 2005. Õigusterminite etümoloogia. - Aime Vettik, Erki Silvet (koost.). Keel ja õigus. Tallinn: Juura, 111-117.

Talvik, Edgar 1936. Rooma õiguslugu. Konspekt. Dotsent dr. jur. Leo Leesmenti loengute alusel. Tartu.

Tavast, Arvi 2004. Mõiste mõiste: tähendusteooriate mõju oskuskeelepraktikale. - Sirje Mäearu (toim.). Rahvusvaheline terminoloogiakonverents "Eesti oskuskeel 2003 " 10. ja 11. oktoobril 2003. Ettekanded. Tallinn: Eesti Keele Sihtasutus, 7-18.

Tiersma, Peter 1999. Legal Language. Chicago, London: The University of Chicago Press.

Vettik, Aime 1996. Oma ja võõras. - Õiguskeel 5, 4-7.

Merike Ristikivi (Tartu Ülikool) on erialalt klassikaline filoloog, uurimisteemaks on ladina keele mõjutused eesti õiguskeeles.

merike.ristikivi@ut.ee 


\section{POLYSEMY AND SYNONYMY OF LATIN TERMS IN ESTONIAN LEGAL LANGUAGE}

\section{Merike Ristikivi}

University of Tartu

The article discusses some problems of polysemy and synonymy occurring in Latin legal language. The material analysed comprises the terms collected for the compilation of the Latin-Estonian Juridical Dictionary (2005). Polysemy is generally avoided in terminology. However, absolute monosemy is not in accordance with the principles of language functioning. The meaning of the term reflects the local conditions and time in which it is used, and its usage may become more specific or more general, or the term may even come to denote a totally different idea. In the case of polysemy the meanings of the terms become distinct first in the common language and legal language. Polysemy also occurs in the legal language across the various areas of law. Different meanings for the same terms have developed in penal power and civil law, for example. The meaning of legal terms also varies in the usage characteristic of different legal systems. Legal language differs from language for other specific purposes in one significant aspect: it is culturally determined, associated with an individual society and its legal system. Even though European legal thinking is generallybased on the common heritage of Roman Law and the terms originating from it have become rooted in modern legal systems, the meanings of Latin legal phrases oftendiverge depending on whether they are used in the Anglo-American legal system or in continental Europe. Smaller differences between the meanings of identical terms can also be found in the use of legal language of Romance and Germanic legal families.

The synonymous variants of Latin legal terms do not vary on the level of legal systems and linguistic boundaries. Synonymy occurs mainly between two single words, but it can also appear between a single word and a phrase, with the latter being more specific. Also, synonymy can be observed between phrases or expressions themselves. Often grammatical and orthographic variants appear, and a term and its abbreviated form may exist in parallel. The most common type of lexical variants is the parallel existence of a foreign term and a native term. The trend is towards using foreign words more readily in professional writings, particularly on the level of international communication and information exchange, whereas native phrases are preferred in more general writings and writings in the native language.

Keywords: legal language, terminology, terminological dictionaries, lexical semantics, language contact, polysemy of terms, synonymy of terms, Latin, Estonian 